\title{
Influence of Teacher-Centered and Student-Centered Teaching Methods on the Academic Achievement of Post-Basic Students in Biology in Delta State, Nigeria
}

\author{
Ezurike Chidubem Precious ${ }^{1,}$, , Ayo-Vaughan Adewunmi Feyisetan ${ }^{2}$ \\ ${ }^{1}$ Administration Department, Barbara Cox Schools, Lagos, Nigeria \\ ${ }^{2}$ Curriculum \& Instruction Department, Federal College of Education (Technical), Asaba, Nigeria \\ Email address: \\ preciouschidubem997@gmail.com(Ezurike C.P.), oluwanikanlomola@gmail.com (Ayo-Vaughan A.F.) \\ ${ }^{*}$ Corresponding author
}

To cite this article:

Ezurike Chidubem Precious, Ayo-Vaughan Adewunmi Feyisetan. Influence of Teacher-Centered and Student-Centered Teaching Methods on the Academic Achievement of Post-Basic Students in Biology in Delta State, Nigeria. Teacher Education and Curriculum Studies.

Vol. 5, No. 3, 2020, pp. 120-124. doi: 10.11648/j.tecs.20200503.21

Received: August 3, 2020; Accepted: August 18, 2020; Published: August 27, 2020

\begin{abstract}
Teaching methods are essential for effective teaching and learning and to a great extent influence academic achievement of students. The objective of this study therefore was to examine the influence of teaching methods on the academic achievement of senior secondary school students in Biology in Oshimili South Local Government Area of Delta State. The descriptive survey research method was adopted in the study. Two research questions were formulated to guide the study. The population of the study comprised 1,550 biology students in public schools in Oshimili South Local Government Area of Delta State. Simple random sampling technique was used to select forty biology students from five randomly selected schools making it a total of two hundred (200) students. A questionnaire titled 'Influence of Teaching Methods on Students' Academic Achievement in Biology Questionnaire (ITMSAABQ) was the main instrument for data collection. Cronbach Alpha analysis was used to test for the reliability of the instrument and it was found reliable with a reliability co-efficient of 0.75 . Data collected was analyzed using descriptive statistics of frequency counts, percentages, mean, and standard deviation. Findings from the study revealed that student-centered teaching method increases students' academic achievement while teacher-centered teaching methods decreases students' academic achievement in biology. The study recommended that teachers should create an environment that will enable students participate fully in the teaching-learning process of biology. Also, State Education Boards should organize seminars to educate biology teachers on the need for and how to use innovative methods in teaching biology.
\end{abstract}

Keywords: Student-Centered, Teacher-Centered, Teaching, Teaching Methods, Academic Achievement

\section{Introduction}

Biology is a very important science subject and stand as the bedrock and prerequisite upon which other science courses like medicine, nursing, pharmacy, genetics, biochemistry, agriculture are based. Biology as a science of life, is one of the subject mostly preferred by many students in the secondary school because it is less mathematical compared to physics and chemistry. It has been observed that Biology has a very high enrolment of student in the Senior School Certificate Examination more than Chemistry and Physics. Regardless of the high number of student's enrollment in Biology in the senior secondary school examinations conducted by West African Examination Council (WAEC) and National Examination Council (NECO), report from scholars and educators backed by the Biology Chief Examiner's report indicated that students' achievement in biology in these external examinations is poor $[6,20]$.

The poor achievement of students in Biology external examinations has been linked to the use of traditional methods of teaching such as lecture, demonstration and discussion methods. These traditional methods of teaching biology stresses more on the transmission of knowledge in 
the manner that emphasizes memorization, hence they have been characterized by some educators $[11,22,13]$ as a poor method of teaching. These teaching methods involve unidirectional flow of information/knowledge from teacher to the student and do not encourage the process skill acquisition needed for proper understanding of biological principles, concepts and facts. These traditional teaching methods are referred to as teacher-centered approaches to learning in the sense that the teacher is seen as the possessor of knowledge [9]. The uni-directional flow of information in the traditional teaching method makes student passive and unable to construct meaningful knowledge in the teaching and learning of biology.

The shortcoming of these traditional teaching methods resulted to the persistent search for an effective method of teaching and learning Biology which culminated into the discovery and suggestion by some researchers $[11,17,5]$ for the use of innovative teaching methods such as project method, field trip and inquiry methods among others. In the innovative teaching and learning process, teachers are not the possessor of knowledge hence the innovative teaching methods are referred to as student-centered approach to learning [7]. This study was therefore carried out to examine the influence of teacher-centered and student-centered teaching methods on the academic achievement of senior secondary school students in Biology in Oshimili South Local Government Area of Delta State.

Science educators have reported a downward trend in the academic achievement of Nigeria student's in science subjects [4]. Biology is among the science subjects affected. The failure rate in biology is even more alarming compared to Chemistry and Physics despite, the fact it is the popular science subject among students [19]. In science curriculum, [15] noted that Biology is one of the major science subjects whose pass at credit level determines the admissibility of students to study major professional science based course at the university. To this end, the manner in which the teaching of this subject takes place cannot be overlooked.

Teaching is an academic process that involves two group of people: the teacher/ instructor and students/learners and information which include knowledge, skills, values and attitude that are transmitted. Due to this activity involved in teaching, the concepts of teaching are preferably discussed as teaching and learning. According to [22] teaching and learning are considered as two sides of a coin, because teaching is meaningless without learning. Hence, teaching without learning is considered mere talking, for teaching to be meaningful it must be effective in promoting knowledge, skills and value.

Teaching methods involve different activities of the teacher and learner such as: questioning, explanation, use of examples and illustrations or demonstration. The activities can be referred to as skills or techniques. The use of these techniques vary with different teaching methods and depend on many factors such as type of learning objectives, nature of subject, age of student, number of student among others. Hence, there are different types of teaching methods such as lecture method, discussion, demonstration, games and simulations, project methods, problem-solving, inquiry method, and field trip among others. These different teaching methods have been grouped by some educators [23, 7] into two approaches: teachers centered and students centered.

Teachers centered approach include all the teaching methods that the teacher dominates in the lesson procedure and takes the lead in coordinating the class room activities as regards to what to be done. For instance in the lecture method, the instructor present fact and principles orally. In view of this, the lecture method has been criticized to be a poor method of teaching hand-skill in science including Biology although it provides for effective use of time and manpower especially in presenting ideas to large group of people.

Considering other teacher-centered approaches, demonstration as a teaching method involves the teacher showing the student a process or procedure step by step. Demonstration method has some advantage over the lecture method in skill acquisition. However, the disadvantages remains that the learner followed the rigidly prescribed procedure by the teacher and this makes it not effective for science teaching. Discussion method which is also among teacher-centered approach is a more advanced teacher-centered approach in which an issue in the learning content is posed as a question by the teacher and each of the student chips in different ideas etc. However, the teacher still determines the content and the questions and takes upper control in the flow of information or knowledge hence they are considered as teacher-centered approach of teaching.

Student-centered approach include all teaching methods that underscore the teacher as a decision maker and problem solver in the classroom but rather sees the teacher as guide, facilitator, mentor, coach, or consultant in the teaching and learning process. In the educational sector the term studentcentered, child-centered or learner-centered are interchangeable used to refer to teaching methods that allow students to share some degree of responsibility and decision making in the classroom. According to [18] studentcentered approach is grounded in constructivism, with the epistemological view that learners are the architects of their own idiosyncratic meanings of concept and natural phenomena. Nevertheless, in today's educational discussion, the term student-centered approach is a broad term that includes all innovative teaching methods that are usually activity oriented, where learners are expected to observe, analyze, synthesize, and evaluate ideas or phenomena using materials or previous knowledge. Teaching methods that emphasizes this approach include project method, constructivist related method (concept mapping, cooperative learning), problem solving, graphic organizers, simulations and games, field trips and inquiry method among others.

The student-centered approach is relevant to Biology teaching because in Biology teaching creating an environment that will encourage students to interact with 
material and specimens enable student to construct meaningful knowledge and learn Biology first hand. In view of the relevance of student-centered approach to teaching and learning of biology, many researchers in Biology education $[11,10,17,20]$ recommend a shift from the use of traditional teaching method (teacher-centered approach) of teaching biology to a modern/innovative teaching methods like project method, field trip and inquiry method etc. consequent on the above, answers to the following questions were sought:

1. What are the most effective methods of teaching biology?

2. What is the influence of teacher-centered (traditional) and student-centered (innovation) teaching methods on the academic achievement of students in biology?

\section{Methods}

\subsection{Research Design}

Survey research design was adopted in the conduct of this study. According to [7], research design is the strategy for study and the plan by which the strategy is to be carried out specifying the methods and the procedure for the data collection, measurement, and analysis of data. The survey research design was considered appropriate since data would be collected from the randomly selected elements in the population without imposing any condition or treatment on them. Thus, the researcher can only describe, explain and or predict events without interfering in functioning of the elements or respondents in the study.

\subsection{Population and Sample}

The population of this study comprised 1,550 senior secondary school students of Oshimili South Local government area of Delta State. Simple random sampling technique was used to select 200 students selected from five public secondary schools in Oshimili South Local Government Area of Delta State that were also randomly selected. The names of these schools are Zappa Mixed Secondary School Asaba, West-End Secondary School Asaba, Osadenis Mixed Secondary School Asaba, Niger Mixed Secondary School Asaba and Asagba Mixed Secondary School Asaba.

\subsection{Data Collection Instrument}

The instrument for data collection was a self-structured questionnaire titled Students' perception of the influence of teaching methods on students' academic achievements in Biology". The instrument was made up of two sections: section A was used to collect information on personal data of the respondents while section B contained ten (10) items designed to measure teaching methods and its influence on the academic achievement of senior secondary school students in Biology using four (4) point Likert scale with responses ranging from strongly Agree (SA), Agree (A), Disagree (D) and Strongly Disagree (SD). Cronbach Alpha Analysis was used to determine the reliability of the instrument and it obtained a reliability coefficient of 0.75 (high). Data gathered was analyzed using descriptive statistics of mean and standard deviation.

Table 1. Mean response scores on the most effective methods of teaching biology.

\begin{tabular}{|c|c|c|c|c|c|c|c|}
\hline STATEMENTS & SA & $\mathbf{A}$ & D & SD & MEAN & Std. Dev & Decision \\
\hline I have never understood any topic in biology through discussion with my fellow students. & 7 & 37 & 124 & 32 & 2.1 & 0.69 & Disagree \\
\hline I find it difficult to learn when we embark on field trip for biological studies. & 12 & 14 & 132 & 42 & 2.0 & 0.72 & Disagree \\
\hline I achieve more and perform well in a class when the teaching is not participatory. & 10 & 18 & 128 & 44 & 2.0 & 0.71 & Disagree \\
\hline $\begin{array}{l}\text { I lose interest easily and do not perform well in a class where my teacher does all the } \\
\text { talking while I listen }\end{array}$ & 19 & 168 & 13 & 0 & 3.0 & 0.41 & Agree \\
\hline $\begin{array}{l}\text { Carrying out research on biology topics when adequately guided has been helping me in } \\
\text { retention and promotes my academic achievement. }\end{array}$ & 19 & 172 & 9 & 0 & 3.05 & 0.37 & Agree \\
\hline
\end{tabular}

Table 1 shows the mean response scores on the most effective ways of teaching Biology. Majority of the respondents expressed disagreement with the following item statements "I have never understood any topic in biology through discussion with my fellow students", "I find it difficult to learn when we embark on field trip for biological studies" and "I achieve more and perform well in a class when the teaching is not participatory" with mean response scores of below the reference mean score of 2.50. However, majority of the respondents expressed agreement with the following item statements "I lose interest easily and do not perform well in a class where my teacher does all the talking while I listen" and "Carrying out research on biology topics when adequately guided has been helping me in retention and promotes my academic achievement" with mean response scores $\geq 2.50$. Analysis of data suggests that discussion method, field trip and participatory methods are the most effective methods of teaching biology while lecture method is less effective.

Table 2 shows mean response scores on the influence' of teachers teaching methods on academic achievement of senior secondary school students in biology. The result shows that majority of the respondents affirmed the following item statements "opportunity to discover things" "enhancement of retention" and "promotion of academic achievement" are ways through which teachers' method of teaching influences students' academic achievement in biology while lack of interest in observation and forgetting easily the topic taught are influences of teacher-centered methods. 
Table 2. Mean response scores on the influence of teachers teaching methods on academic achievement of senior secondary school students in biology.

\begin{tabular}{|c|c|c|c|c|c|c|c|}
\hline STATEMENTS & SA & $\mathbf{A}$ & D & SD & Mean & $\begin{array}{l}\text { Std. } \\
\text { Dev. }\end{array}$ & Decision \\
\hline I perform better in tests from topics where I am given opportunity to discover things myself. & 93 & 80 & 17 & 10 & 3.3 & 0.82 & Agree \\
\hline I like discovering new things about a topic in biology than rely only on what the teacher taught. & 97 & 98 & 3 & 2 & 3.5 & 2.6 & Agree \\
\hline Excursions and field trips enhance my retention and promote my academic achievement. & 69 & 108 & 18 & 5 & 3.2 & 3.1 & Agree \\
\hline I like observing my teacher alone, perform an experiment in biology class. & 14 & 21 & 127 & 38 & 2.06 & 0.76 & Disagree \\
\hline $\begin{array}{l}\text { Each time I do assignments and carry out project in biology topic, I do forget easily when asked } \\
\text { questions from that same topic. }\end{array}$ & 2 & 14 & 158 & 26 & 1.96 & 0.49 & Disagree \\
\hline
\end{tabular}

\section{Discussion}

The findings of this study has shown that discussion method, field trip and other participatory methods are the most effective methods of teaching biology while lecture method is less effective. This finding aligns with that of [21] which stated that field trip and participatory methods of teaching are more effective in teaching Biology because they offer an opportunity to motivate and connect students to appreciate and understand classroom concepts which increase a students' knowledge foundation, promoting further learning and higher level thinking strategies. Similarly, [24] stated that teacher-centered methods like lecture, demonstration among others are less effective due to the fact that they are less practical, more theoretical and memorizing. It does not encourage students to learn real life problems based on applied knowledge.

The study also found that "opportunity to discover things" "enhancement of retention" and "promotion of academic achievement" are ways through which student-centered methods of teaching influences students' academic achievement in Biology while "lack of interest in observation" and "forgetting easily the topic taught" are influences of teacher-centered methods. This findings is in agreement with the findings of $[1,14,16]$ which maintained that using innovative teaching methods would encourage students to learn better, understand and retain biology concepts and promotes their future involvement. In addition, it also aligns with the findings of $[3,12,25]$ that poor methods which are mostly teacher-centered and conventional teaching methods adopted by teachers in teaching Biology at the senior secondary schools level in Nigeria has been identified as one of the major factors contributing to poor performance of students in biology. Similarly, [2, 3, 25] also stated that persistent use of this methods makes students passive rather than active learners, encourages loss of interest, does not promotes insightful learning and long-term retention on some abstract concepts in Biology.

\section{Conclusion}

This study has looked at teaching methods and its' influence on the academic achievements of senior secondary school students in biology. It has revealed that the use of teacher-centered (traditional) methods could be attributed to poor academic achievement of students in Biology and that the use of student-centered methods (innovative) are the most effective in enhancing students' achievement in Biology in senior secondary schools.

The focus of teaching today has also changed from being teacher-centered to student-centered. This trend cannot be disconnected from the finding that student-centered methods offer an opportunity to motivate and connect students to appreciate and understand classroom concepts which increase a students' knowledge foundation, promoting further learning and higher level thinking strategies. Thus, teachers of a subject like Biology which is voluminous, activity-packed and abstract in nature cannot but make use of the most appropriate methods.

\section{Recommendations}

This study therefore recommended that State Education Boards should organize seminars to educate biology teachers on the need for innovative teaching methods in teaching biology and how to effectively use the innovative methods. Also, school authorities should be supportive both financially to biology teachers whenever they want to embark on teaching activities or study programmes that will expose them to the use of various innovative strategies. Finally, teachers should be conscious of creating an environment that will enable students participate fully in the teaching and learning of biology.

\section{References}

[1] Adegoke, B. A. (2010). Integrating animations, narrations and textual materials for improving students' learning outcomes in senior secondary schools physics. Electronic Journal of Research in Educational Psychology, 8 (2), 725-748.

[2] Ahmed, M. A. (2008). Influence of personality factors on biology lecturers assessment of difficulty levels of genetic concepts in Nigerian colleges of education. (Unpublished doctoral thesis of University of Ilorin, Ilorin, Nigeria.

[3] Ahmed, M. A, \& Abimbola, I. O. (2011). Influence of teaching experience and school location on biology teachers' rating of the difficult levels of nutrition concepts in Ilorin, Nigeria, JOSTMED, 7 (2), 52-61.

[4] Ajagun, G. A. (2001). A study of the performance of science students in the senior secondary schools certificate examinations in selected schools in Kaduna State. Tambari Kano Journal of Education. 6 (2), 114-117.

[5] Akpan, E. B. (2010). Effect of competitive and cooperative learning strategies on Academic achievement of Nigeria student. In: Biology Educational Research Review 3 (1), 33-37. 
[6] Biology Chief Examiners' Report (2007). Reports on students' academic performance on WAEC and NECO in biology. https://www.examinations/chiefexaminers report/biology.

[7] Campbell, M. A. (2006). The effect of the 5E learning cycle model on students' understanding of force and motion concept. Unpublished M. Ed Thesis University of Central Florida, Orlando Florida.

[8] Cooper, D. R., \& Schindler, P. S. (2006). Business Research Methods $\left(9^{\text {th }}\right.$ edition). USA: McGraw - Hill.

[9] Guisti, B. M. (2005). Comparison of guided and open inquiry instruction in high school physics classroom. Unpublished M. $\mathrm{SC}$ thesis. School Of Technology Brigham Young University.

[10] Ibe, E. (2004). Effect of guided-inquiry and demonstration on science process skills acquisition among biology secondary school students. Unpublished M. Ed thesis Department of Science Education. University Of Nigeria Nsukka.

[11] Ibe, E. and Nwosu, A. A. (2003). Effect of guided, inquiry and demonstration on science process skills acquisition among secoy school biology students. Journal of Science Teachers Association of Nigeria, 38 (1 and 2), 58-63.

[12] Kareem, L. O. (2013). Effects of audio-graphic selfinstructional packages on senior secondary school students performance in biology in Ilorin Nigeria. Unpublished Ph. D Thesis of the University of Ilorin, Ilorin.

[13] Kirshner, P. A, Sweller, J. and Clark, R. E. (2006). 'why minimal guidance during instruction doesn't work: An analysis of the failure of constructivist, discovery, problembased, experiment and inquiry-based teaching. Educational psychologist, 41 (2), 75-78.

[14] Kuti, J. B. (2006). Effects of multimedia instructional strategy on senior sec students learning outcomes in physics in Ogun State, Nigeria. (Unpublished master's project) University of Ibadan, Ibadan, Nigeria.

[15] Lawal, F. K. (2010). Error Analysis on practical biology of senior secondary school students. In Zaria and Sabon Gari Local government area of Kaduna state. Unpublished M. Ed Thesis. Ahmadu Bello University, Zaria.
[16] Mayer, R. E, Dow, G. T, Mayer, S. (2003). Multimedia learning in an interactive self-explaining environment. What works in the design of elagent-based micro world's? Journal of Educational psychology, 95, 806-813.

[17] Nwagbo, C. R. (2006). Effect of two teaching methods on achievement and attitude to biology student of different levels of scientific literacy. International Journal of Educational Research. 216-229. Retrieved from www.elsevier.com/local/ijdures

[18] O'Bannon, C. (2002). Defining inquiry: Exploring the many types of inquiry in the science classroom. The science Teacher Springer Link-Foundation of Science. 1 (1), 34-37.

[19] Ogunleye, O. A. (2009). Teachers' and students' perception of problem solving difficulties in physics: implication for remediation. Journal of Teaching and Learning, 6 (7), 85-90.

[20] Opara, J. A. (2011). Inquiry method and students' academic achievement in biology: lessons and policy implication: American - Eurasian Journal of Scientific Research, 6 (1), 2831.

[21] Rennie, L. J. (2007). Learning outside of school. In S. K Abeil \& NG. lederman (Eds). Handbook of research on science education. Mahwag, New Jersey: Erlbaum.

[22] Sawa, M. M. (2011). Typologies of instrumental methods strategies and techniques. In Nzeribe A. C. B and Sawa M. M. (Eds). Principles and methods of teaching. Yola, Nigeria Paraclete Publishers.

[23] Shawnee State University. (2001). Inquiry professional conceptual framework. Unpublished Thesis. Shawnee State University. Teacher Education Department.

[24] Teo, R \& Wong. A. (2000). "Does problem based learning create a better student: A reflection? Paper presented at the 2nd Asia pacific conference on problem based learning. Education Across Disciplines, December 4-7, Singapore.

[25] Umar, A. A. (2011). Effects of biology practical activities on students' process skills acquisition in Minna Niger-State, Nigeria. JOSTMED, 7 (2), 118-126. 